Received: March 8, 2010

Accepted after revision: June 16, 2010 Published online: November 26, 2010

\title{
Immediate-Type Hypersensitivity to Succinylated Corticosteroids
}

\author{
Annett Isabel Walker ${ }^{a}$ Helen-Caroline Räwer ${ }^{a}$ Wolfgang Sieber ${ }^{b}$ \\ Bernhard Przybilla ${ }^{a}$ \\ ${ }^{a}$ Klinik und Poliklinik für Dermatologie und Allergologie, AllergieZENTRUM, Ludwig-Maximilians-Universität, \\ München, und ${ }^{b}$ Abteilung für Pneumologie und Allergologie, Kreiskrankenhaus Wörth an der Donau, \\ Wörth, Deutschland
}

\section{Established Facts}

- In recent years, immediate-type reactions to succinylated corticosteroids, probably related to the succinate moiety, have been reported quite frequently.

\section{Novel Insights}

- This case report reviews present knowledge on immediate-type reactions to succinylated corticosteroids and highlights the role of the basophil activation test, a helpful diagnostic tool in identifying the causative agents.

\section{Key Words}

Anaphylaxis · Corticosteroids • Succinic acid •

Basophil activation test

\begin{abstract}
Background: Despite their frequent use, systemic corticosteroids have rarely elicited immediate-type reactions. $\mathbf{O b}$ jective: We report two male patients, aged 26 and 70 years, respectively, with severe immediate-type hypersensitivity secondary to the administration of corticosteroids esterified with succinate. Methods: Skin tests, basophil activation tests and challenge tests were performed for diagnostic evaluation. Results: In both patients, immediate-type skin test re-
\end{abstract}

actions were found to methylprednisolone sodium hemisuccinate $(\mathrm{MSH})$ and prednisolone sodium hemisuccinate (PSH). In contrast, nonsuccinylated corticosteroids (including methylprednisolone and prednisolone in one patient) yielded no test reactions. Basophils from one patient exhibited a stimulated expression of the activation marker CD63 upon in vitro incubation with PSH or hydrocortisone sodium succinate, but not with hydrocortisone. Skin tests and basophil activation tests were negative in controls. One patient was challenged with the incriminated drugs. He developed flush, conjunctivitis, tachycardia and dyspnea 2 min after injection of $\mathrm{MSH}$, and dyspnea shortly after intravenous administration of PSH. Oral and intravenous challenge tests with nonsuccinylated corticosteroids were tolerated well by

\section{KARGER}

Fax +4161306 1234 E-Mail karger@karger.ch www.karger.com
(C) 2010 S. Karger AG, Basel

$1018-2438 / 11 / 1551-0086 \$ 38.00 / 0$

Accessible online at:

www.karger.com/iaa
Correspondence to: Dr. med. Annett Isabel Walker

Klinik und Poliklinik für Dermatologie und Allergologie

Ludwig-Maximilians-Universität, Frauenlobstrasse 9-11

DE-80337 München (Germany), Tel. +49 895160 6010, Fax +49 8951606594

E-Mail annett.walker@med.uni-muenchen.de 
both patients. Conclusions: These case reports should alert clinicians to rare, but severe immediate-type reactions to corticosteroids, related to the succinate moiety in our patients. In case of allergic reactions to corticosteroids, it is mandatory to identify the causative agent and find safe alternatives.

Copyright $\odot 2010$ S. Karger AG, Basel

\section{Introduction}

Corticosteroids are rarely suspected as causative agents of immediate-type hypersensitivity as their antiallergic properties would seem to contradict their capacity to induce such reactions. However, worsening of allergic symptoms during corticosteroid therapy may not always indicate treatment failure. Therefore, the possibility of corticosteroid hypersensitivity has to be considered.

Immediate-type reactions such as sneezing, angioedema, generalized urticaria, bronchospasm, hypotension or even anaphylactic shock have been observed after oral, intravenous, intramuscular, subcutaneous, or intra-articular administration of corticosteroids [1]. Approximately 100 cases of immediate-type hypersensitivity to corticosteroids have been reported [1-3]. The pathomechanism of these reactions has remained unclear in most patients, but positive skin test reactions or specific IgE antibodies to the suspected elicitors were found in some patients [3-17]. Challenge tests were performed in just a few cases, and most of them were positive $[5,8,14,18-20]$.

We here report two patients with immediate-type reactions to corticosteroids whose test results indicate immediate-type allergy to the succinate moiety of succinylated corticosteroids to be the underlying pathomechanism of hypersensitivity.

\section{Case Report}

\section{Patient 1}

History

In 2000, a then 26-year-old male developed flush and dyspnea after being stung by a yellow jacket. He received an intravenous injection of prednisolone sodium hemisuccinate (PSH, SoluDecortin ${ }^{\circledR} \mathrm{H}$ ), whereupon his symptoms worsened. In 2004, he again experienced a systemic reaction after a yellow jacket sting, and was treated with intravenous methylprednisolone sodium hemisuccinate $\left(\mathrm{MSH}, \mathrm{Urbason}^{\circledR}\right.$ solubile), clemastine fumarate $\left(\right.$ Tavegil ${ }^{\circledR}$ ) and presumably dimethindene maleate (Fenistil $\left.{ }^{\circledR}\right)$. He developed anaphylactic shock within 15 min after administration of these drugs. The patient recovered from both episodes without sequelae. Skin examination revealed no manifestations of mastocytosis; baseline serum tryptase concentration was $8.3 \mu \mathrm{g} / \mathrm{l}$ (95th percentile in normals, $11.4 \mu \mathrm{g} / \mathrm{l})$.

Allergological Tests

Skin prick tests with three commercial injectable corticosteroid solutions, i.e. PSH $5 \mathrm{mg} / \mathrm{ml}$ (Solu-Decortin H), MSH $1.6 \mathrm{mg}$ / $\mathrm{ml}$ (Urbason solubile) and hydrocortisone sodium succinate (HSS) $50 \mathrm{mg} / \mathrm{ml}$ (Hydrocortison rotexmedica), induced positive reactions (wheal diameter $4 \mathrm{~mm}$ ) after $20 \mathrm{~min}$; in contrast, neither corticosteroids without a succinate moiety, nor other succinylated substances, or succinic acid itself $\left(2.5 \mathrm{mg} / \mathrm{ml}\right.$; Sigma-Aldrich ${ }^{\circledR}$, Munich, Germany) yielded positive skin prick test reactions (table 1$)$. Histamine dihydrochloride $(0.1 \%)$ served as positive control and elicited a positive reaction (wheal diameter $4 \mathrm{~mm}$ ). There was no skin test reaction to physiological saline (negative control). In five healthy volunteers, skin prick tests performed as described above with PSH, MSH and HSS were negative. In addition, skin prick tests with a standard series of common aeroallergens were performed in the patient, and revealed positive reactions (wheal diameter 3-6 mm) to numerous allergens. Assessment of patient's serum with CAP-FEIA (Phadia, Freiburg, Germany) revealed specific IgE antibodies to yellow jacket (16.0 kU/l; CAP class 3$)$ and bee venom $(0.78 \mathrm{kU} / \mathrm{l}$; CAP class 2$)$, but no specific IgE antibodies to natural rubber latex. Total IgE was $241 \mathrm{kU} / \mathrm{l}$ (normal range $<100 \mathrm{kU} / \mathrm{l}$ ). A basophil activation test was performed using the Flow2 CAST system (Bühlmann Laboratories, Schönenbuch, Switzerland). Briefly, EDTA whole blood was incubated with prednisolone sodium phosphate, PSH and HSS at different concentrations as well as with formyl-methionyl-leucyl-phenylalanine (fMLP), which served as positive control, and stimulation buffer (negative control). A staining reagent containing monoclonal antibodies to human CD63 (activation marker on basophils) labeled with fluorescein isothiocyanate (anti-CD63-FITC) and to human chemokine receptor CCR3 (basophil marker) labeled with phycoerythrin (anti-CCR3-PE) was added. Cells were then analyzed by flow cytometry. The corticosteroids did not induce basophil activation in this test; the positive control yielded a stimulation of $18.15 \%$.

To prove that $\mathrm{PSH}$ and $\mathrm{MSH}$ were the eliciting compounds in a single-blind manner, placebo-controlled challenge tests were performed. In accordance with current guidelines for drug provocation tests [21], incremental doses of PSH (1, 5, 10, 50, $100 \mathrm{mg})$ and $\mathrm{MSH}(2,8,15,75 \mathrm{mg})$ were administered intravenously on different days at intervals of $90 \mathrm{~min}$ after placement of an intravenous line and under close monitoring in the intensive care unit $[21,22]$. Shortly after administration of $100 \mathrm{mg}$ PSH, the patient became dyspneic. Two minutes after injection of $75 \mathrm{mg} \mathrm{MSH}$, he developed flush, conjunctivitis, tachycardia and dyspnea. In contrast, intravenous challenge tests with a succinate-free corticosteroid preparation (dexamethasone sodium phosphate, Dexa-ratiopharm ${ }^{\circledR}$; maximum single dose: $40 \mathrm{mg}$ ), clemastine fumarate (Tavegil; maximum single dose: $2 \mathrm{mg}$ ) and dimethindene maleate (Fenistil; maximum single dose $4 \mathrm{mg}$ ) as well as oral challenges with betamethasone (Celestamine ${ }^{\circledR}$ N 0.5 liquidum; maximum single dose: $9 \mathrm{mg}$ ), doxylamine succinate (Sedaplus ${ }^{\circledR}$ Saft; maximum single dose $30 \mathrm{mg}$ ) and DL- $\alpha$-tocopheryl acid succinate (Merz Spezial Dragees; maximum single dose: $10 \mathrm{mg}$ ) were tolerated well. 
Table 1. Test results in patient 1

\begin{tabular}{|c|c|c|c|}
\hline Agent & Preparation & Skin prick test & Challenge test \\
\hline Prednisolone sodium hemisuccinate & Solu-Decortin $(50 \mathrm{mg} / \mathrm{ml})$ & $4 \mathrm{~mm}(5 \mathrm{mg} / \mathrm{ml})$ & positive (max. single dose $100 \mathrm{mg}$, i.v.) \\
\hline Methylprednisolone sodium hemisuccinate & Urbason solubile $(16 \mathrm{mg} / \mathrm{ml})$ & $4 \mathrm{~mm}(1.6 \mathrm{mg} / \mathrm{ml})$ & positive (max. single dose $75 \mathrm{mg}$, i.v.) \\
\hline Hydrocortisone sodium succinate & Hydrocortison rotexmedica $(50 \mathrm{mg} / \mathrm{ml})$ & $4 \mathrm{~mm}(50 \mathrm{mg} / \mathrm{ml})$ & ND \\
\hline Dexamethasone sodium phosphate & Dexa-ratiopharm $(8 \mathrm{mg} / \mathrm{ml})$ & & negative (max. single dose 40 mg, i.v.) \\
\hline Methylprednisolone & Urbason $(40 \mathrm{mg})$ & & ND \\
\hline Prednisolone & Decortin H (5 mg) & & ND \\
\hline Triamcinolone acetonide dipotassium phosphate & Volon A solubile $(40 \mathrm{mg} / \mathrm{ml})$ & & ND \\
\hline Betamethasone & Celestamine $\mathrm{N}(0.5 \mathrm{mg} / \mathrm{ml})$ & & negative (max. single dose $9 \mathrm{mg}$, orally) \\
\hline Hydrocortisone & Hydrocortison Hoechst $(5 \mathrm{mg} / \mathrm{ml})$ & & ND \\
\hline Prednisolone sodium phosphate & hefasolon i.v. $(8 \mathrm{mg} / \mathrm{ml})$ & & ND \\
\hline Dl- $\alpha$-tocopheryl acid succinate & Merz Spezial Dragees (10 mg) & & negative (max. single dose $10 \mathrm{mg}$, orally) \\
\hline Doxylamine succinate & Sedaplus Saft $(2.5 \mathrm{mg} / \mathrm{ml})$ & & negative (max. single dose $30 \mathrm{mg}$, orally) \\
\hline Gelatine polysuccinate & Gelafundin $4 \%(40 \mathrm{mg} / \mathrm{ml})$ & & ND \\
\hline Clemastine fumarate & Tavegil $(0.4 \mathrm{mg} / \mathrm{ml})$ & & negative (max. single dose $2 \mathrm{mg}$, i.v.) \\
\hline Dimethindene maleate & Fenistil $(1 \mathrm{mg} / \mathrm{ml})$ & & negative (max. single dose $4 \mathrm{mg}$, i.v.) \\
\hline Succinic acid/Sigma-Aldrich, Munich, Germany & & $(2.5 \mathrm{mg} / \mathrm{ml})$ & ND \\
\hline
\end{tabular}

Skin prick tests and challenge tests were performed with the commercial preparations unless otherwise indicated. ND = Not done; i.v. $=$ intravenously.

Table 2. Test results in patient 2

\begin{tabular}{|c|c|c|c|c|}
\hline Agent & Preparation & Skin prick test & Intradermal test & Challenge test \\
\hline Prednisolone sodium hemisuccinate & Solu-Decortin $(50 \mathrm{mg} / \mathrm{ml})$ & & $12 \mathrm{~mm}(0.5 \mathrm{mg} / \mathrm{ml})$ & ND \\
\hline Methylprednisolone sodium hemisuccinate & Urbason solubile $(16 \mathrm{mg} / \mathrm{ml})$ & & $10 \mathrm{~mm}(0.16 \mathrm{mg} / \mathrm{ml})$ & ND \\
\hline Triamcinolone acetonide dipotassium phosphate & Volon A solubile $(40 \mathrm{mg} / \mathrm{ml})$ & & & ND \\
\hline Hydrocortisone sodium succinate & $\begin{array}{l}\text { Hydrocortison rotexmedica } \\
(50 \mathrm{mg} / \mathrm{ml})\end{array}$ & & & ND \\
\hline Succinic acid/Sigma-Aldrich, Munich, Germany & & $(2.5 \mathrm{mg} / \mathrm{ml})$ & ND & ND \\
\hline Dexamethasone disodium phosphate & Fortecortin $(10 \mathrm{mg} / \mathrm{ml})$ & ND & ND & negative (max. single dose $60 \mathrm{mg}$, i.v.) \\
\hline Prednisolone & Decortin H $(50 \mathrm{mg})$ & ND & ND & negative (max. single dose $50 \mathrm{mg}$, orally) \\
\hline
\end{tabular}

Skin prick tests and challenge tests were performed with the commercial preparations unless otherwise indicated. ND $=$ Not done; i.v. $=$ intravenously.

Yellow jacket venom immunotherapy was started. In addition, he was provided with an emergency kit containing betamethasone (Celestamine N 0.5 liquidum) and dimethindene maleate (Fenistil) for oral self-application, self-injectable adrenaline (Anapen ${ }^{\circledR}$ ) and dexamethasone sodium phosphate (Dexa-ratiopharm) for intravenous injection by a physician in case of emergency.

\section{Patient 2}

History

A 70-year-old male patient had received PSH- and HSS-containing preparations intravenously because of acute hearing loss. He started to develop nausea and vomiting within seconds, and finally he lost consciousness. Emergency treatment including administration of adrenaline was performed, and he recovered without sequelae. Medical history included stenosis of the carotid artery, cardiovascular disease, hypertension and hyperuricemia. Skin examination was without pathological findings. Baseline serum tryptase concentration was $5.1 \mu \mathrm{g} / 1$ (95th percentile in normals: $11.4 \mu \mathrm{g} / \mathrm{l})$.

\section{Allergological Assessment}

The patient presented 15 years after the reaction. Skin prick tests with 4 corticosteroids and succinic acid were negative (table 2). Intradermal tests were positive (wheal diameter $12 \mathrm{~mm}$ ) for both PSH $0.5 \mathrm{mg} / \mathrm{ml}$ (Solu-Decortin H) and MSH $0.16 \mathrm{mg} / \mathrm{ml}$ (Urbason solubile) (wheal diameter $10 \mathrm{~mm}$ ) whereas intradermal tests with HSS $0.5 \mathrm{mg} / \mathrm{ml}$ (Hydrocortison rotexmedica) and triamcinolone acetonide dipotassium phosphate $1 \mathrm{mg} / \mathrm{ml}$ (Volon ${ }^{\circledR}$ A solubile) yielded negative results. There was no skin test reac- 

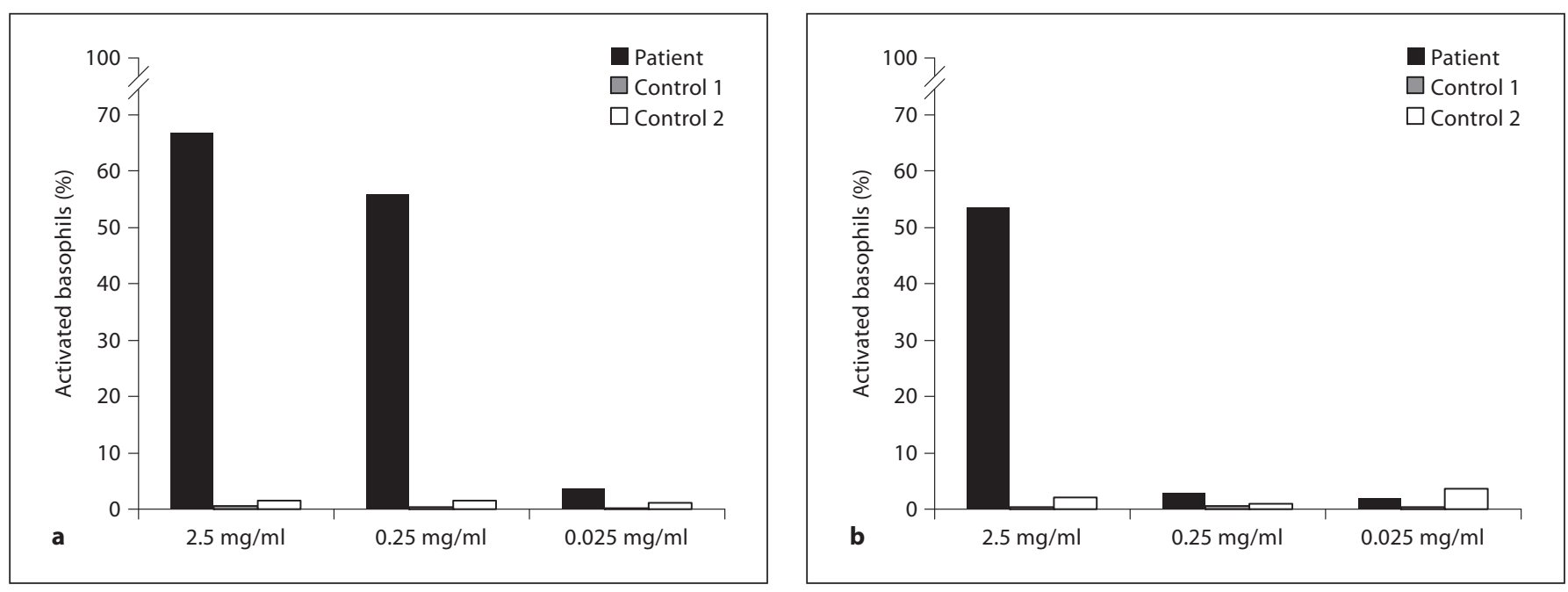

Fig. 1. Percentage of activated basophils from patient 2 and two unaffected controls after incubation with prednisolone sodium succinate (a) and hydrocortisone sodium succinate (b). There was no activation of basophils by hydrocortisone without the succinate moiety.

tion to intradermal physiological saline (negative control); histamine dihydrochloride $(0.1 \%)$ yielded a strongly positive reaction (wheal diameter $8 \mathrm{~mm}$ ) in the skin prick test.

Basophil activation tests with peripheral blood cells from the patient and from two nonatopic controls without a history of corticosteroid hypersensitivity were done using the Basotest ${ }^{\circledR}$ (Orpegen Pharma, Heidelberg, Germany). In brief, heparinized whole blood was incubated with PSH, HSS and hydrocortisone at different concentrations as well as with fMLP (positive control) and Basotest stimulation buffer (negative control). Cells were double stained with a phycoerythrin-conjugated antibody to human IgE (identifying basophil granulocytes) and a fluorescein-conjugated antibody to glycoprotein gp53 (CD63) expressed on activated basophils. Cell characteristics were determined by flow cytometry. Analysis of the CD63 expression of the patient's cells revealed significant positive responses to PSH and HSS at various concentrations but not to hydrocortisone (fig. 1). There was no activation of basophils from the two controls.

Because of the patient's general condition and multiple concomitant diseases, he was not challenged with the incriminated drugs. However, intravenous challenges with dexamethasone disodium phosphate (Fortecortin ${ }^{\circledR}$ Inject; maximum single dose 60 $\mathrm{mg}$ ) and oral challenges with prednisolone (Decortin $\mathrm{H}$; maximum single dose $50 \mathrm{mg}$ ), which are both succinate-free, were performed and well tolerated.

\section{Discussion}

Skin prick or intradermal tests were positive to PSH and MSH in both patients - in patient 1 also to hydrocortisone sodium succinate. A challenge test was done in patient 1 with PSH and MSH and caused systemic symp- toms. Patient 2 was not challenged with the incriminated drugs because of his general condition and multiple concomitant diseases. Based on history and test results, we made a diagnosis of immediate-type hypersensitivity to certain corticosteroids, which, in view of positive skin and in vitro tests, probably has an immunological basis. Hypersensitivity was restricted to succinylated compounds as various corticosteroids without the succinate moiety were tolerated well.

To make corticosteroids water-soluble for intravenous application, they are often esterified with succinic acid, phosphoric acid or others, primarily at the C21 position [23]. Especially succinate esters seem to have a sensitizing potential [13]. Because of their low molecular weight, corticosteroids probably act as haptens [24-26].

In patient 1 , basophil activation tests using the Flow2 CAST system remained negative. In patient 2 , expression of the activation marker CD63 was induced on basophils by PSH and HSS but not by hydrocortisone; cells from two healthy controls showed no reaction. The positive basophil activation tests with cells from patient 2 corroborated the diagnosis of hypersensitivity to succinylated corticosteroids, particularly as challenge tests with the suspected agents could not be performed. The discrepant results of the basophil activation test obtained with cells from patient 1 or patient 2 may be related to the different methodology used, but cells from patients with definite IgE-mediated allergy do not always react to the respective allergen in this test system [27-29]. 
Table 3. Synopsis of diagnostic results in published cases of systemic immediate-type hypersensitivity to succinylated corticosteroids

\begin{tabular}{|c|c|c|c|c|c|}
\hline $\begin{array}{l}\text { Eliciting agent } \\
\text { (as given by the original authors) }\end{array}$ & $\begin{array}{l}\text { Skin } \\
\text { prick test }\end{array}$ & $\begin{array}{l}\text { Intradermal } \\
\text { test }\end{array}$ & $\begin{array}{l}\text { Challenge test with } \\
\text { the eliciting agent }\end{array}$ & Other diagnostics & $\begin{array}{l}\text { Refer- } \\
\text { ence }\end{array}$ \\
\hline $\begin{array}{l}\text { Methylprednisolone hydrogen succinate } \\
\text { (patient 1) }\end{array}$ & positive & ND & positive & & {$[18]$} \\
\hline $\begin{array}{l}\text { Methylprednisolone hydrogen succinate } \\
\text { (patient 2) }\end{array}$ & negative & positive & ND & & \\
\hline Methylprednisolone sodium succinate & negative & positive & ND & & {$[16]$} \\
\hline Methylprednisolone succinate & positive & positive & ND & $\begin{array}{l}\text { demonstration of specific IgE antibodies } \\
\text { to methylprednisolone succinate negative }\end{array}$ & {$[15]$} \\
\hline Hydrocortisone succinate & ND & ND & ND & & {$[40]$} \\
\hline Methylprednisolone sodium succinate & ND & positive & ND & & {$[7]$} \\
\hline Methylprednisolone sodium succinate & positive & positive & ND & & {$[26]$} \\
\hline Methylprednisolone sodium succinate & ND & positive & ND & & {$[25]$} \\
\hline Methylprednisolone sodium succinate & negative & positive & ND & & {$[12]$} \\
\hline Prednisolone sodium succinate & positive & ND & ND & & {$[4]$} \\
\hline Methylprednisolone sodium succinate & positive & positive & ND & & {$[9]$} \\
\hline Methylprednisolone sodium succinate & positive & ND & ND & $\begin{array}{l}\text { demonstration of specific IgE antibodies to } \\
\text { methylprednisolone sodium succinate positive }\end{array}$ & {$[11]$} \\
\hline Methylprednisolone sodium hemisuccinate & positive & positive & positive & & {$[35]$} \\
\hline Hydrocortisone sodium succinate & positive & positive & positive & & {$[14]$} \\
\hline Hydrocortisone sodium succinate & ND & positive & ND & $\begin{array}{l}\text { demonstration of specific IgE antibodies to } \\
\text { hydrocortisone sodium succinate negative }\end{array}$ & {$[3]$} \\
\hline Methylprednisolone sodium succinate & ND & positive & ND & scratch test positive & {$[17]$} \\
\hline Hydrocortisone hemisuccinate & positive & ND & ND & & {$[38]$} \\
\hline Methylprednisolone sodium succinate & positive & ND & ND & & {$[6]$} \\
\hline Prednisolone hemisuccinate & negative & $\begin{array}{l}\text { positive } \\
\text { (in } 3 / 4 \text { patients) }\end{array}$ & ND & $\begin{array}{l}\text { demonstration of specific IgE antibodies to } \\
\text { prednisolone hemisuccinate negative }\end{array}$ & {$[39]$} \\
\hline
\end{tabular}

$\mathrm{ND}=$ Not done.

It has been claimed that immediate-type hypersensitivity reactions to corticosteroids could be triggered by nonimmunological mechanisms [17]. In some of the cases with negative prick tests, idiosyncrasy similar to reactions to acetylsalicylic acid was suspected [30]. In these cases, inhibition of cyclooxygenase is suggested to cause bronchospasm by blocking prostaglandin production which results in increased leukotriene production [30, 31]. Others suggested that some of these reactions, such as cardiovascular collapse, can be explained by rapid infusion of a considerable amount of corticosteroids, causing a decrease in cardiac output, secondary to $\alpha$-adrenergic blockade and a negative inotropic effect $[32,33]$.

Asthma, nonsteroidal anti-inflammatory drug hypersensitivity and multiple high-dose applications of corticosteroids in the past have been considered to be risk factors for immediate-type hypersensitivity to corticosteroids [11], which may also be encountered more often in patients with atopic conditions or renal transplants [17].
However, these associations are vague, and current data do not support any unequivocal host factors that may predispose patients to corticosteroid hypersensitivity [17].

In recent years, immediate-type hypersensitivity reactions to succinylated corticosteroids have been described quite frequently $[3,4,6,7,9,11,12,14-16,18,24-26,34-$ 41] whereas such reactions to succinate-free corticosteroids seem to be less frequent $[2,5,10,19,20,42-44]$. A number of patients had positive skin prick tests to the eliciting and related corticoidsteroids $[11,26,45,46]$. Specific serum IgE antibodies to corticosteroids were demonstrated in a few cases $[11,24,42]$.

In agreement with our results, 4 patients who experienced immediate-type reactions after administration of $\mathrm{MSH}$, but who tolerated methylprednisolone without the succinate moiety well have been reported $[15,16,18]$. Koutsostathis and Vovolis [15], for example, reported 1 female patient who experienced an anaphylactic shock 
after receiving MPS. Both, skin prick and intradermal tests were positive for MPS and hydrocortisone succinate. Koutsostathis and Vovolis challenged the patients only with nonsuccinylated corticosteroids. Challenge tests with succinylated corticosteroids (e.g. MPS) and other succinylated noncorticosteroid compounds were not performed [15]. In addition, we performed a basophil activation test. Besides our patients, there have been other cases related to this topic (table 3). However, it is not yet known how often corticosteroid hypersensitivity is restricted to succinylated compounds as it seems that the type of esterification has not always been considered. Immediate-type hypersensitivity to succinate salts as such has not been reported so far [4], nor have we found any reactions to succinic acid or other compounds than corticosteroids bearing the succinate moiety in patient 1 . However, though the succinate fraction was comparable in doxylamine succinate (15.1 $\mathrm{mg}$ succinate per $50 \mathrm{mg}$ ), MSH (12.4 mg succinate per $50 \mathrm{mg}$ ) and PSH (12.8 mg succinate per $50 \mathrm{mg}$ ), the maximum allowed daily dose of doxylamine succinate was $50 \mathrm{mg}$ whereas the administered doses of MSH or PSH were 100 or $166 \mathrm{mg}$, respectively. Also, in contrast to intravenous challenge tests with succinylated corticosteroids, oral challenge tests were performed with succinylated noncorticosteroid compounds.
Currently, anaphylactic reactions to other succinylated noncorticosteroid compounds in patients reporting immediate-type hypersensitivity to succinylated corticosteroids cannot be completely excluded. Though a challenge test with doxylamine succinate was well tolerated by one of our patients; it was just an oral challenge test with a low dose. Challenge tests with injectable succinylated noncorticosteroid compounds, in particular (e.g. gelatine polysuccinate), were not performed. Further studies have to clearly unravel this question.

In summary, it is important to be aware of the possibility of immediate hypersensitivity to corticosteroids in order to select treatment accordingly. Adequate allergological diagnosis is necessary in such patients not only to identify the culprit compound, but also to find a suitable corticosteroid for future intravenous treatment. Furthermore, such tolerated corticosteroids should be included in the patient's emergency kit.

\section{Acknowledgments}

We thank M. Rolle, S. Gassner and A. Versec for skilled technical assistance.

\section{References}

1 Kamm GL, Hagmeyer KO: Allergic-type reactions to corticosteroids. Ann Pharmacother 1999;33:451-460.

2 Caduff C, Reinhart WH, Hartmann K, Kuhn M: Allergische sofortreaktionen auf parenterale Glukokortikosteroide? Analyse von 14 Fällen. Schweiz Med Wochenschr 2000;130: 977-983.

3 Fulcher DA, Katelaris CH: Anaphylactoid reaction to intravenous hydrocortisone sodium succinate: a case report and literature review. Med J Aust 1991;154:210-214.

4 Kurzhals G GH, Agathos M, Breit R: Anaphylaktische Reaktion auf Succinatester von Kortikosteroiden. Allergologie 1995;18:156158.

5 Venturini M, Lobera T, del Pozo MD, Gonzalez I, Blasco A: Immediate hypersensitivity to corticosteroids. J Investig Allergol Clin Immunol 2006;16:51-56.

6 Sieck JO, al-Ohaly Y, Saour J, Khan M, Henriquez $\mathrm{H}$ : An allergic reaction to intravenous methylprednisolone administration. $\mathrm{Br} \mathrm{J}$ Clin Pract 1990;44:723-725.
7 Saito R, Moroi S, Okuno H, Ogawa O: Anaphylaxis following administration of intravenous methylprednisolone sodium succinate in a renal transplant recipient. Int J Urol 2004;11:171-174.

8 Rasanen L, Hasan T: Allergy to systemic and intralesional corticosteroids. Br J Dermatol 1993;128:407-411.

9 Doezema D: Anaphylaxis following administration of intravenous methylprednisolone sodium succinate. Am J Emerg Med 1987;5: 42-44.

10 Erdmann SM, Abuzahra F, Merk HF, Schroeder A, Baron JM: Anaphylaxis induced by glucocorticoids. J Am Board Fam Pract 2005; 18:143-146.

11 Burgdorff T, Venemalm L, Vogt T, Landthaler M, Stolz W: IgE-mediated anaphylactic reaction induced by succinate ester of methylprednisolone. Ann Allergy Asthma Immunol 2002;89:425-428.

12 Rao KV, Andersen RC, O’Brien TJ: Successful renal transplantation in a patient with anaphylactic reaction to solu-medrol (methylprednisolone sodium succinate). Am J Med 1982;72:161-163.
13 Mace S, Vadas P, Pruzanski W: Anaphylactic shock induced by intra-articular injection of methylprednisolone acetate. J Rheumatol 1997;24:1191-1194.

14 Holz W, Ludwig A, Forst H: Anaphylactic shock following intravenous hydrocortisone succinate administration (in German). Anaesthesist 2002;51:187-190.

15 Koutsostathis N, Vovolis V: Severe immunoglobulin E-mediated anaphylaxis to intravenous methylprednisolone succinate in a patient who tolerated oral methylprednisolone. J Investig Allergol Clin Immunol 2009;19: 330-332.

16 Gelincik A, Yazici H, Emre T, Yakar F, Buyukozturk S: An alternative approach to a renal transplant patient who experienced an immediate type systemic reaction due to methylprednisolone sodium succinate. J Investig Allergol Clin Immunol 2009;19:162-163.

17 Butani L: Corticosteroid-induced hypersensitivity reactions. Ann Allergy Asthma Immunol 2002;89:439-445.

18 Caimmi S, Caimmi D, Bousquet PJ, Demoly P: Succinate as opposed to glucocorticoid itself allergy. Allergy 2008;63:1641-1643. 
19 Lopez-Serrano MC, Moreno-Ancillo A, Contreras J, Ortega N, Cabanas R, Barranco $\mathrm{P}$, Munoz-Pereira M: Two cases of specific adverse reactions to systemic corticosteroids. J Investig Allergol Clin Immunol 1996; 6:324-327.

20 Mendelson LM, Meltzer EO, Hamburger RN: Anaphylaxis-like reactions to corticosteroid therapy. J Allergy Clin Immunol 1974;54:125-131.

21 Przybilla B, Aberer W, Bircher AJ, Brehler R, Brockow K, Dickel H, Fuchs T, Hertl M, Mockenhaupt M, Pfaar O, Ring J, Sachs B, Vieluf D, Wedi B, Worm M, Zuberbier T, Merk HF: Allergologische Diagnostik von Überempfindlichkeitsreaktionen auf Arzneimittel. J Dtsch Dermatol Ges 2008;6:240243.

22 Aberer W, Bircher A, Romano A, Blanca M, Campi P, Fernandez J, Brockow K, Pichler WJ, Demoly P: Drug provocation testing in the diagnosis of drug hypersensitivity reactions: general considerations. Allergy 2003; 58:854-863.

23 Anderson BD, Conradi RA, Knuth KE: Strategies in the design of solution-stable, watersoluble prodrugs. I. A physical-organic approach to pro-moiety selection for 21-esters of corticosteroids. J Pharm Sci 1985;74:365374.

24 Pryse-Phillips WE, Chandra RK, Rose B: Anaphylactoid reaction to methylprednisolone pulsed therapy for multiple sclerosis. Neurology 1984;34:1119-1121.

25 Peces R, Gorostidi M, Azofra J, Sanchez L, Alvarez J: Anaphylaxis following intravenous methylprednisolone sodium succinate in a renal transplant recipient. Nephron 1991;59:497-498.

26 Freedman MD, Schocket AL, Chapel N, Gerber JG: Anaphylaxis after intravenous methylprednisolone administration. JAMA 1981; 245:607-608
27 Sanz ML, Gamboa PM, Antepara I, Uasuf C, Vila L, Garcia-Aviles C, Chazot M, De Weck AL: Flow cytometric basophil activation test by detection of CD63 expression in patients with immediate-type reactions to betalactam antibiotics. Clin Exp Allergy 2002;32: 277-286.

28 Erdmann SM, Ventocilla S, Moll-Slodowy S, Sauer I, Merk HF: Basophil activation tests in the diagnosis of drug reactions (in German). Hautarzt 2005;56:38-43.

29 Eberlein B, Leon Suarez I, Darsow U, Rueff F, Behrendt H, Ring J: A new basophil activation test using CD63 and CCR3 in allergy to antibiotics. Clin Exp Allergy 2010;40:411418.

30 Dajani BM, Sliman NA, Shubair KS, Hamzeh YS: Bronchospasm caused by intravenous hydrocortisone sodium succinate (SoluCortef) in aspirin-sensitive asthmatics. J Allergy Clin Immunol 1981;68:201-204.

31 Frieri M: Corticosteroid effects on cytokines and chemokines. Allergy Asthma Proc 1999; 20:147-159.

32 Husum B, Palm T, Andersen K, Vejlsted H: Immediate hemodynamic effect of pharmacological doses of methylprednisolone in dogs, and the influence of speed of injection. Acta Anaesthesiol Scand 1980;24:61-64.

33 McDougal BA, Whittier FC, Cross DE: Sudden death after bolus steroid therapy for acute rejection. Transplant Proc 1976;8:493496.

34 Escribano-Rodriguez MM, Gonzalez-Pol J, Munoz-Bellido FJ, de la Calle-Toral A, Velazquez-Amor E, Conde-Hernandez J: Immediate reaction to methylprednisolone with tolerance of other corticosteroids. Allergy 1997;52:677-678.

35 Fernandez S, Reano M, Vives R, Borja J, Daroca $P$, Canto G, Rodriguez J: 6-Methylprednisolone-induced bronchospasm. Allergy 1997;52:780-782.

36 Mansfield LE, Ting S, Haverly RW: Anaphylaxis caused by the sodium succinate ester of hydrocortisone and methylprednisolone. J Asthma 1986;23:81-83.

37 Laine-Cessac P, Moshinaly H, Gouello JP Geslin P, Allain P: Severe anaphylactoid reactions after intravenous corticosteroids: report of a case and review of the literature (in French). Therapie 1990;45:505-508.
38 Calogiuri GF, Muratore L, Nettis E, Ventura MT, Ferrannini A, Tursi A: Anaphylaxis to hydrocortisone hemisuccinate with crosssensitivity to related compounds in a paediatric patient. Br J Dermatol 2004;151:707708 .

39 Alexiou C, Kau RJ, Luppa P, Arnold W: Allergic reactions after systemic administration of glucocorticosteroid therapy. Arch Otolaryngol Head Neck Surg 1998;124: 1260-1264.

40 Currie GP, Paterson E, Keenan F, Nath S, Watt SJ: An unexpected response to intravenous hydrocortisone succinate in an asthmatic patient. Br J Clin Pharmacol 2005;60: 342

41 Nakamura H, Matsuse H, Obase Y, Mitsuta K, Tomari S, Saeki S, Kawano T, Kondo Y, Machida I, Shimoda T, Asai S, Kohno S: Clinical evaluation of anaphylactic reactions to intravenous corticosteroids in adult asthmatics. Respiration 2002;69:309-313.

42 Rasanen L, Tarvainen K, Makinen-Kiljunen S: Urticaria to hydrocortisone. Allergy 2001; 56:352-353

43 Polosa R, Prosperini G, Pintaldi L, Rey JP, Colombrita R: Anaphylaxis after prednisone. Allergy 1998;53:330-331.

44 Hama K, Nakahata K, Iranami H, Hatano Y: Immediate allergic reaction to betamethasone during anesthesia. Anesth Analg 2006; 102:1904-1905.

45 Chapman SC, Loughnan BA, Somerfield SD: Immediate hypersensitivity skin testing in a case of hydrocortisone anaphylaxis: case report. NZ Med J 1979;90:380.

46 Moreno-Ancillo A, Martin-Munoz F, Martin-Barroso JA, Diaz-Pena JM, Ojeda JA: Anaphylaxis to $6 \alpha$-methylprednisolone in an eight-year-old child. J Allergy Clin Immunol 1996;97:1169-1171. 